\title{
STIGMATIZING ATTITUDES AND THE USE OF STIGMATIZING LANGUAGE TOWARDS MENTAL ILLNESS AMONG DOCTORS AND NURSES IN TURKEY
}

\author{
Kirci Ercan Seda, ${ }^{1}$ Delba Hakan Dursun ${ }^{2}$ \\ ${ }^{1}$ University of Health Sciences, Konya Training and Research Hospital, Psychiatry Clinic, Konya, Turkey \\ ${ }^{2}$ University of Health Sciences Izmir Bozyaka Training and Research Hospital, Psychiatry Clinic, Izmir, Turkey \\ Primljen/Received 02. 12. 2020. god. \\ Prihvaćen/Accepted 20. 06. 2021. god.
}

Abstract: Introduction: It is common knowledge that individuals with mental illness face many negative consequences of stigmatization. They are also super sensitive to the attitudes of health professionals. This study aims to investigate the stigmatizing attitudes and language usage of mental health professionals and to compare them with non-mental health professionals.

Material and Methods: A total of 722 healthcare professionals were asked to complete the sociodemographic characteristics data form, the questionnaire including the list of stigmatizing words for mental illnesses, and the Attitudes Towards Mentally Ills Scale (ATMIS).

Results: Research shows that mental health professionals have less stigmatizing attitudes when compared to other healthcare professionals $(\mathrm{p}=.000)$. However, it is determined that there is no difference in terms of the number of stigmatizing words used by both groups, and the most frequently used psychiatric diagnostic expressions with stigmatizing purposes are personality disorders. The number of stigmatizing words used by physicians is more than nurses $(p=.000)$. Mental healthcare professionals have more positive attitudes in both short-term and the long term relationship scale scores. Both groups show that the mean score is lower in long-term than in short-term relationships.

Conclusion: Working in the mental health field does not lead to a positive change in terms of language use in stigmatizing purposes and reducing stigmatizing attitudes in a long-term relationship with individuals with mental illness. It is recommended to increase the awareness of physicians about the use of stigmatizing language.

Keywords: Stigmatization, attitudes, doctor, nurse, mental illness, language.

\section{INTRODUCTION}

Stigmatization is defined as the perception of the person by the society in which he lives in an unusual, discredited, and disrespectful way (1). The first and largest group of stigmatization in most societies are people with mental illness (2). Stigmatizing attitudes of society prevent the stigmatized people from seeking treatment; it can lead to consequences such as discrimination, loneliness, stress, violence, and suicide $(3,4)$. Studies suggest they are exposed to exclusionary attitudes by the public for reasons such as being considered aggressive, inconsistent, and unpredictable behavior, misinformation of the public through the media, and cultural characteristics of the society (5).

Researches have reported that healthcare professionals may also share some social prejudices against mental illnesses $(6,7)$, which may impair the quality of care (6-11). Because of their stigmatizing attitudes, general medical conditions accompanying mental illness are diagnosed later and poorly treated. This can lead to a shorter life expectancy for these individuals even when suicide and accidents are excluded $(12,13)$.

There are also stigmatizing attitudes towards individuals with mental illness among mental healthcare professionals (MHCPs) $(8,14)$. Some studies comparing MHCPs attitudes with other colleagues report that they display less stigmatizing attitudes than others (15, 16 ), while some studies say the opposite (17). When it comes to studies comparing the attitudes of physicians and nurses, some indicate that nurses have a more negative attitude (18), while others show no difference (19). In conclusion, the results of the comparison of stigmatizing attitudes of healthcare professionals are not consistent in the literature. Besides, the fact is that 
stigmatization attitude researches on mental illnesses in healthcare professionals in our country have been conducted in a single center, and the sample numbers are relatively low $(9,11,20)$.

Healthcare professionals thoughts, speech styles, language use, and forms of expression about individuals with mental illnesses are important when reflecting their attitudes and behaviors towards these patients $(20,21)$. Studies suggest that healthcare professionals should be more attentive in paying attention to the words they choose, how and for what purpose psychiatric diagnoses are used (22). The awareness of healthcare professionals has to be increased in terms of not using mental illness diagnoses in a stigmatizing manner $(20,22)$.

This study aims to research the stigmatizing attitudes and language usage of MHCPs and compare them with healthcare professionals working outside the mental health field. Our first assumption is that MHCPs have a more positive attitude and use stigmatizing words less than other healthcare professionals (OHCPs). The second is that physicians have more positive attitudes than nurses and use stigmatizing words less.

\section{MATERIAL AND METHODS}

The research was conducted between 01.02.201901.05.2019 by delivering questionnaires and scales (Google forms) to the healthcare professional groups via the Internet (social media, professional e-mail groups, etc.). The research questionnaires and scales were prepared in a way that the participants could only participate once and send after replying all questions without leaving them blank. After their informed consent was obtained, the participants were provided to fill in anonymously and without time restrictions. All physicians and nurses who answered all the questions in different parts of Turkey were included in the study. Healthcare professionals working in the field of mental health for less than a year were excluded. The study was approved by the Ethical Committee of the Izmir Bozyaka Training and Research Hospital (Approval no 2019/11).

\section{Measures}

Sociodemographic data form: The form requested the sociodemographic and professional information of the participants. One question asked the participants if any mental disease or disorder was used in a way that was mocking or humiliating by them. The words in the question were inspired by the same words used in a similar study before, and the total score was calculated by accepting each word as a score (20).

Attitudes Towards Mentally Ills Scale (ATMIS): It was developed to provide information about the ap- plicability of the treatment approach in the community. It begins with an exemplary case (vignette) that fillers should consider in responding to attitude items. It is a 5-point Likert-type scale consisting of 22 items, and its validity and reliability study has been performed. Also, the scale has two subscale scores, namely shortterm relationship and long-term relationship (23). The overall high score indicates a positive attitude.

\section{Statistical analysis}

All data were analyzed with SPSS 21 statistical software. Data are mean, standard deviation, and percentage distributions, as well as descriptive statistical methods; Among the parametric tests, Student's t-test was compared to categorical variables using the chi-square test. The statistical value of $p<0.05$ was considered significant. One-way analysis of variance was performed to test whether more than two independent groups differ significantly in terms of mean scale scores. Cohen's d value was found to be 1.00 when the type 1 error of the study was accepted as .05 and post hoc power analysis was performed with the scale means and standard deviations of the groups. This value showed that the number of samples and statistical results of the research were of beneficial impact (24).

\section{RESULTS}

A total of 722 healthcare professionals participated in the study. $282(39.1 \%)$ were adult psychiatrists, $106(14.7 \%)$ were child psychiatrists, $112(\% 15.5)$ were mental health nurses, 188 (26\%) were other healthcare physicians (specialists in other fields, general practitioners), and $34(\% 4.7)$ were other healthcare nurses. The details of the sociodemographic data and the number of professionals in occupational groups are in Table 1. The data of the participants were divided into two groups as mental healthcare professionals (MHCPs) and other fields' healthcare professionals (OHCPs). The professionals in the field of mental health like psychiatrists, child psychiatrists, and psychiatric nurses constituted MHCPs group $(\mathrm{n}=$ 500, 69.3\%); specialist doctors (e.g. general surgeons, cardiologists, etc.) and nurses working outside the mental health field and general practitioners constituted OHCPs group $(n=222,30.7 \%)$. There was no statistically significant difference between the two groups except for gender $(p=.004)$.

A comparison of the stigmatization attitude scores of the healthcare professionals and the number of stigmatizing words used is given in Table 2. The long-term relationship mean score was lower in the whole sample than the short-term relationship mean score. According to the status of working in mental health, when 
Table 1. Sociodemographic data and occupations of health care professionals

\begin{tabular}{|c|c|c|c|c|}
\hline & $\begin{array}{c}\text { MHCP } \\
(\mathrm{n}=500) \\
(\mathrm{Mean} \pm \mathrm{SD})\end{array}$ & $\begin{array}{c}\text { OHCP } \\
(\mathrm{n}=222) \\
(\text { Mean } \pm \mathrm{SD})\end{array}$ & $t / X^{2}$ & $P$ \\
\hline Age (year) & $42.16 \pm 11.7$ & $42.52 \pm 12.09$ & -0.37 & .707 \\
\hline \multirow[t]{2}{*}{ Education (year) } & $16.99 \pm 3.83$ & $17.23 \pm 3.82$ & -0.79 & .425 \\
\hline & Number $(\%)$ & Number (\%) & & \\
\hline \multicolumn{5}{|l|}{ Gender } \\
\hline Female & $367(73.4 \%)$ & $185(83.3 \%)$ & 8.42 & .004 \\
\hline Male & $133(26.6 \%)$ & $37(16.7 \%)$ & & \\
\hline \multicolumn{5}{|l|}{ Occupation } \\
\hline $\begin{array}{l}\text { Mental } \\
\text { Healthcare } \\
\text { Physician }\end{array}$ & $388(53.7 \%)$ & & & \\
\hline $\begin{array}{l}\text { Mental } \\
\text { Healthcare } \\
\text { Nurse }\end{array}$ & $112(15.5 \%)$ & & & \\
\hline $\begin{array}{l}\text { Other } \\
\text { Healthcare } \\
\text { Physician }\end{array}$ & $188(26 \%)$ & & & \\
\hline $\begin{array}{l}\text { Other } \\
\text { Healthcare } \\
\text { Nurse }\end{array}$ & $34(4.7 \%)$ & & & \\
\hline
\end{tabular}

MHCP: Mental health care professionals, n:number of subjects, OHCP: Health care professionals working outside the mental health field, SD: Standard Deviation, $\mathrm{p}<.05$ is statistically significant.

Table 2. Comparison of the stigmatization attitude scores of the health care professionals and the number of stigmatizing words used

\begin{tabular}{|l|c|c|c|c|}
\hline & $\begin{array}{c}\text { MHCP } \\
(\mathrm{n}=500) \\
(\text { Mean } \pm \text { SS })\end{array}$ & $\begin{array}{c}\text { OHCP } \\
(\mathrm{n}=222) \\
(\text { Mean } \pm \text { SS })\end{array}$ & $z / t$ & $P$ \\
\hline $\begin{array}{l}\text { Short Term } \\
\text { Relationship }\end{array}$ & $43.40 \pm 6.47$ & $38.08 \pm 6.92$ & 2.86 & .005 \\
\hline $\begin{array}{l}\text { Long Term } \\
\text { Relationship }\end{array}$ & $34.22 \pm 7.38$ & $29.26 \pm 7.625$ & .33 & .000 \\
\hline $\begin{array}{l}\text { ATMIS Total } \\
\text { Score }\end{array}$ & $77.62 \pm 12.66$ & $67.33 \pm 13.46$ & 9.87 & .000 \\
\hline $\begin{array}{l}\text { Number of } \\
\text { Words Used* }\end{array}$ & $4.25 \pm 3.11$ & $1.31 \pm .462$ & -0.85 & .394 \\
\hline
\end{tabular}

MHCP: Mental healthcare professionals, n: number of subjects, OHCP: Healthcare professionals working outside the mental health field, SD: Standart Deviation, $\mathrm{p}<.05$ is statistically significant.

* Participants were asked to mark the terms determined by researchers for condescending, humiliatingand / or mocking purposes for individuals who do not have mental disorders. Each term is accepted as 1 point and the total score is calculated.

the groups were compared in terms of the number of stigmatizing words they used, there was no difference between them $(p=.394)$. Top three most common used stigmatizing words by MHCPs were Antisocial ( $\mathrm{n}=$ $215,61.8 \%)$, Border $(\mathrm{n}=164,47.1 \%)$, Narcissistic (n $=129,37.1 \%)$; by OHCPs were Obsessive $(\mathrm{n}=144$, $48.8 \%)$, Antisocial $(\mathrm{n}=124,42 \%)$, Psychopath $(\mathrm{n}=$ 114, 38.6\%). Distributions of stigmatizing words used by groups are given in Figures 1 and 2 .
All samples were divided into four groups according to their professions and were compared in terms of ATMIS total attitude score and the number of stigmatizing words used. ATMIS's total attitude score of mental health physicians and mental health nurses was higher than the other two groups $(\mathrm{p}=.000)$. Among the occupational groups, the number of stigmatizing words used by the physicians was higher than the nurses (Table 3). 
Table 3. Comparison of health care professionals in terms of total scores of ATMIS and the number of stigmatizing words used by occupational groups

\begin{tabular}{|c|c|c|c|c|c|c|c|}
\hline & OCCUPATION & $\mathrm{N}$ & $\mathrm{X}$ & $\mathrm{SD}$ & $\mathrm{F}$ & $\mathrm{P}$ & $\begin{array}{c}\text { Relationship } \\
\text { Between } \\
\text { Groups }\end{array}$ \\
\hline $\begin{array}{c}\text { ATMIS Total } \\
\text { Score }\end{array}$ & $\mathrm{A}$ & 388 & 43.69 & 6.241 & 34.55 & .0000 & $\mathrm{~A}=\mathrm{B}>\mathrm{C}=\mathrm{D}$ \\
\hline & $\mathrm{B}$ & 112 & 42.20 & 7.174 & & & \\
\hline & $\mathrm{C}$ & 188 & 38.23 & 6.890 & & & \\
\hline & $\mathrm{D}$ & 34 & 37.24 & 7.144 & & & \\
\hline $\begin{array}{c}\text { Number of } \\
\text { Stigmatizing } \\
\text { Words }\end{array}$ & $\mathrm{A}$ & 388 & 4.40 & 3.022 & 7.70 & .000 & $\mathrm{~A}=\mathrm{C}>\mathrm{B}=\mathrm{D}$ \\
\hline & $\mathrm{B}$ & 112 & 3.32 & 2.918 & & & \\
\hline & $\mathrm{C}$ & 188 & 4.76 & 3.290 & & & \\
\hline & $\mathrm{D}$ & 34 & 2.85 & 2.862 & & & \\
\hline
\end{tabular}

A: Adult and child-adolescent psychiatrists, ATMIS: Attitudes Towards Mentally Ills Scale, B: Nurses working in the mental health field, C: Physicians working outside the mental health field, D: Nurses working outside the mental health field. F: Anova test value, $\mathbf{n}$ : number of subjects, $\mathbf{S D}$ : Standart Deviation, $\mathrm{p}<.05$ is statistically significant

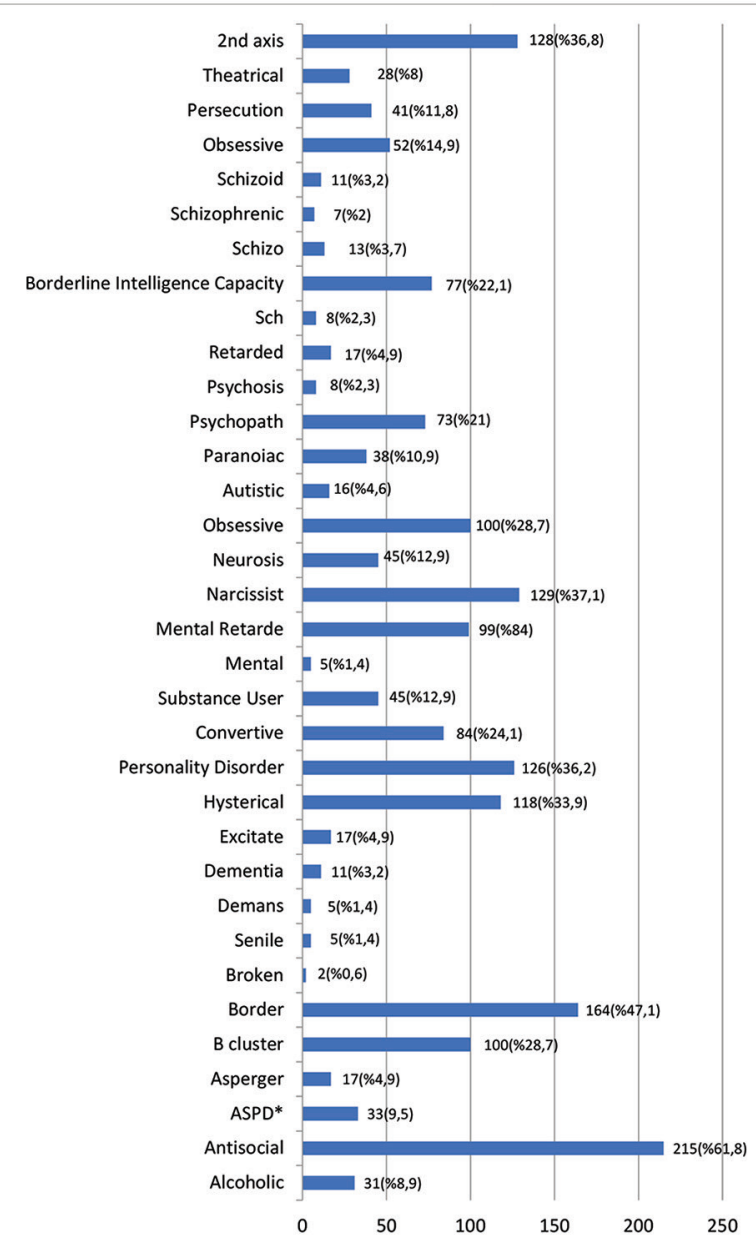

Figure 1. Rates of mental health terms used for stigmatizing purposes by mental health care professionals

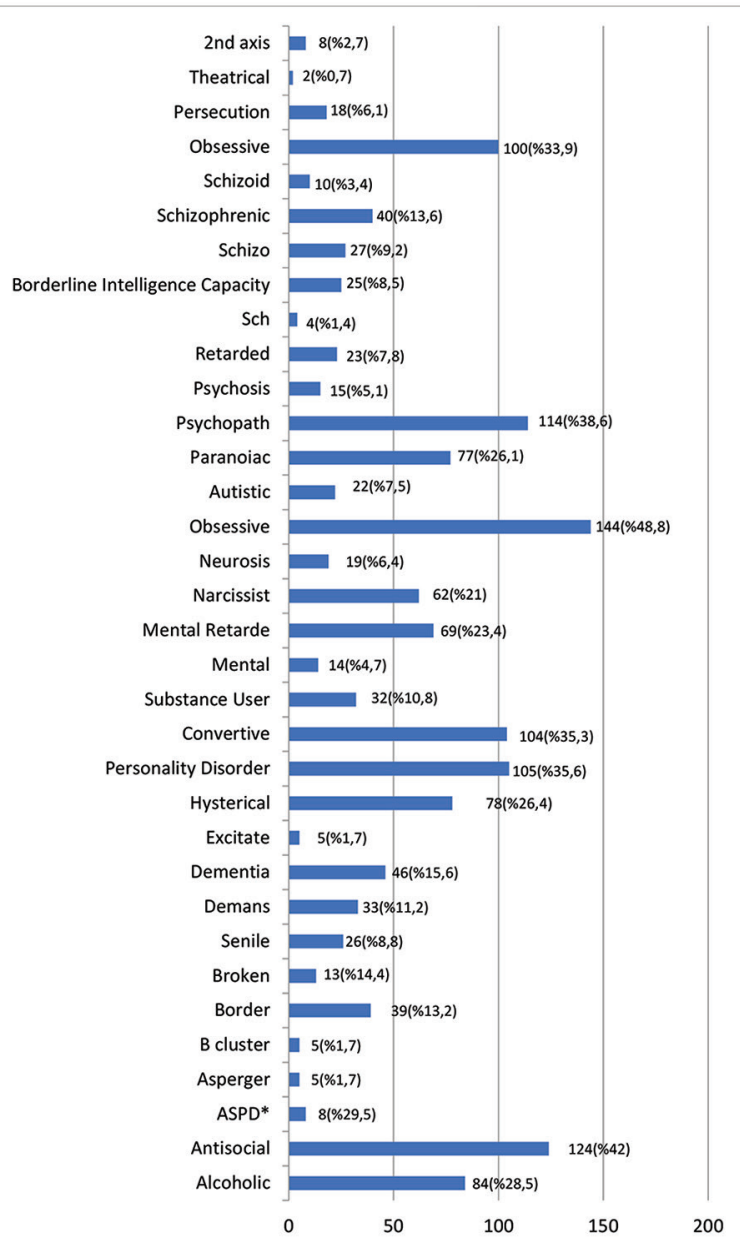

Figure 2. Rates of mental health terms used for stigmatizing purposes by other health care professionalstically significant 


\section{DISCUSSION}

This study shows that physicians and nurses working in mental health have more positive attitudes than those working in other health fields, while the number of stigmatizing words used by the physicians is higher than in nurses. MHCPs stigmatize individuals with mental illness less frequently $(19,25,26,27)$. So the conclusion is that spending more time with people with mental illness, having direct experience with them, and having experienced the disorder itself may be related to a positive attitude $(25,28,29)$. Granados-Gámez et al. explained that personal contact with patients with mental illness works as a good starting point in forming less-stigmatizing attitudes toward mental illness (29). The results of our study support the studies reporting that there are less stigmatizing attitudes among healthcare professionals who are in close contact with mental illnesses. However, other studies are reporting that close contact or being educated on this issue increases the stigmatizing attitude $(30,31)$. For example, nurses working in psychiatry clinics had a more social distance to schizophrenia patients than nurses working in other clinics (31). The reasons such as a lack of adequate training regarding treatment and identification of mental disorders, not knowing how to approach individuals with mental illness, having no interaction with these patients, the effects of stigmatization on the healthcare professional, patient and patient's relative, different qualifications of their working conditions may cause this negative attitude (19). Reports show that some stereotypical beliefs formed in healthcare professionals are similar to the ones in society. The misconception that individuals with mental illness are dangerous, unpredictable, violent, and strange are based on the media and historical misrepresentation and causes fear (8).

The belief that the cause of these illnesses are factors such as moral weakness, character, or willpower; laziness; malingering; lack of discipline, or lack of self-control can lead to hostility and accusation of healthcare professionals (8). Results might differ because of using different scales and because of diverse demographic characteristics. Another reason for these different results related to the relationship between stigma and close contact may also have potential implications for the desire for social acceptance (32). Participants may have answered the research questions in a socially acceptable way, especially considering that the issue of stigmatization is being researched. To reduce the effect of this confounding factor, we have ensured that our study was asked to answer anonymous.

Another result of our research is that MHCPs show more positive attitudes than OHCPs in terms of both the short-term relationship sub-dimension (situations that do not threaten the personal space of the respondent; shopping, traveling, etc. ) and long-term relationship sub-dimension (situations where there is a close social relationship; renting their home, working together in the same place, etc. ) scale scores of ATMIS. On the other hand, all healthcare professionals have a more negative attitude towards situations that require long-term and closer relationships than shortterm ones with individuals with mental illness. In terms of social distance, MHCPs tend to have both positive and negative attitudes according to different variables in many situations requiring both short and long-term relationships, and they are also a mixed group in terms of attitudes $(6,19,25,33,34)$. It can be argued that attitudes of all health professionals are negatively affected for situations that require a longer-term relationship with individuals with mental illness. Our results are similar to the results of Chen et al.'s research, which examines the attitudes of staff working in a psychiatric hospital towards people with mental illness and reported that they had less positive attitudes in a long-term relationship (35). Understandably, the participants behave more conservatively in this regard, as long-term situations requiring close relationships may depend on many factors, but it can be considered a situation with negative consequences. However, the strategy of using MHCPs as role models or opinion leaders in anti-stigmatizing campaigns will not be achieved without noticing and reducing their stigmatizing actions in their daily life (27). MHCPs should be aware that their attitudes are negative for long-term relationships towards people with mental illness, and should improve their knowledge about discrimination against them.

Considering that the language used has the power to shape the way people think, feel and act against each other, the role of non-discriminatory language use in combating stigmatization becomes crucial (36). Reports show that using language that emphasizes the individual instead of the disease (for example, "person with schizophrenia" instead of "schizophrenic") should be supported, and the opposite causes more stigmatizing attitudes and perceptions $(36,37)$. In our study, although the stigmatizing attitude scores were more positive, there was no difference between the MHCPs and OHCPs in terms of the number of stigmatizing words. This may be related to MHCPs use of psychiatric diagnoses as stigmatizing as OHCPs. Similar to the result of a single-center study in our country, our study shows that MHCPs use stigmatizing words mostly about personality traits and disorders (20). Personality disorders are labeled as "incurable, manipulative, trying to attract attention" by healthcare professionals. It is one of the potential stigmas among mental 
disorders and the use of these words with stigmatizing purposes may cause negative effects in terms of treatment results $(38,39)$. When comparing occupational groups (physicians and nurses) in terms of the number of words used for stigmatizing purposes, physicians used more words than nurses.

We have not found a similar result in the literature on stigmatizing language use. In addition, this result is in contradiction with the studies reporting that the stigmatizing attitude decreases as the level of education increases (17). This may be because the number of terms that physicians know is higher than nurses and that they label the patient groups that they find challenging in their professional practices. There is also the possibility that the number of words used in a stigmatizing form doesn't necessarily mean more stigmatizing attitudes.

\section{Strengths and Limitations}

There are some limitations to our study. Since there is no valid and reliable scale to measure the use of stigmatizing language, a questionnaire about the use of stigmatizing language for mental illness was made for our study. In addition, because our study is cross-sectional, the direction of cause and effect relationships can not be confirmed. On the other hand, professionals who have chosen to participate in this study may be more sensitive and knowledgeable about stigmatization. In our sample, the fact that those working in mental health and those working in other fields are not similar in terms of gender may also have affected our results. There are inconsistent results in studies regarding the effect of gender on stigmatizing attitudes. There are studies suggesting that gender may affect attitudes towards individuals with mental disorders, as well as studies suggesting the contrary $(9,32,39,40)$. Another limitation is that other healthcare professionals are compared with mental healthcare professionals as a collective group, and they have not been evaluated separately as subgroups according to the branches they work in. In future studies, we suggest examining the differences between healthcare professionals' use of language and their attitudes towards patients with mental illness, considering the branches they work in. Despite all these limitations, we hope our study will contribute to the literature because of investigating the stigmatizing attitudes of many healthcare professionals from many different centers according to similar studies conducted in our country before.

\section{CONCLUSION}

Although MHCPs have more positive attitudes against individuals with mental illness than OHCPs, this difference decreases when stigmatizing word usage and long-term relationship are evaluated. Negative attitudes should be reduced by providing anti-stigmatization training to healthcare professionals both at the beginning of their careers and in-service even though it might be difficult because of professionals' time constraints and different priorities. All healthcare professionals must be aware of their stigmatizing attitude and its consequences on the life of mentally ill individuals. We recommend creating regulations, which will enable healthcare professionals can be more exposed to these patients in both their education and work, as well as going through theoretical training on mental illnesses. An important part of fighting stigma is avoiding using stigmatizing language and expressions towards people with mental illnesses and stop using psychiatric diagnoses in derogatory meanings. All healthcare professionals need to be aware of the language and terms they use. Current anecdotal evidence for such processes suggests further study about interventions to decrease stigma in this area is needed.
Abbreviations
MHCPs - Mental Healthcare Professionals
OHCPs - Other Healthcare Professionals
ATMIS - Attitudes Towards Mentally Ills Scale

\section{Acknowledgment}

None.

Conflict of Interests: The authors declare that there are no conflicts of interest related to this article.

Funding: None

\section{Licensing}

This work is licensed under a Creative Commons Attribution 4.0 International (CC BY 4.0) License 


\title{
Sažetak
}

\section{STIGMATIZIRANJE DUŠEVNIH BOLESTI I KORIŠĆENJE JEZIKA KOJI PODRŽAVA TU VRSTU STIGME MEĐU LEKARIMA I MEDICINSKIM SESTRAMA U TURSKOJ}

\author{
Kirci Ercan Seda, ${ }^{1}$ Delba Hakan Dursun ${ }^{2}$ \\ ${ }^{1}$ University of Health Sciences, Konya Training and Research Hospital, Psychiatry Clinic, Konya, Turkey \\ ${ }^{2}$ University of Health Sciences Izmir Bozyaka Training and Research Hospital, Psychiatry Clinic, Izmir, Turkey
}

Uvod: Opšte je poznato da se individue sa mentalim bolestima suočavaju sa negativnim posledicama društvene stigmatizacije. Takođe su posebno osetljivi na ponašanje zdravstvenih radnika. Ova studija ima za cilj da ispita stigmatizirajuće stavove i upotrebu jezika stručnjaka za mentalno zdravlje i da ih uporedi sa stručnjacima koji to nisu.

Material i metode: Od ukupno 722 zdravstvena radnika zatraženo je da popune obrazac sa podacima o sociodemografskim karakteristikama, upitnik koji uključuje spisak stigmatizirajućih reči za mentalne bolesti i skalu stavova prema mentalnim bolestima (ATMIS).

Rezultati: Istraživanja pokazuju da stručnjaci za mentalno zdravlje imaju manje stigmatizirajuće stavove u poređenju sa drugim zdravstvenim radnicima $(\mathrm{p}=$ .000). Međutim, utvrđeno je da nema razlike u pogle-

\section{REFERENCES}

1. Link BG, Phelan JC. Conceptualizing stigma. Am Rev Sociol 2001; 27(1): 363-85. Doi: 10.1146/annurev. soc.27.1.363.

2. Cancro R, Meyerson AT. Prevention of disability and stigma related to schizophrenia. In Schizophrenia, WPA series evidence and experience in Psychiatry. Maj M, Sartorius N, editors. New York: John Wiley\& Sons Ltd; 1999: 269-71.

3. Fung KMT, Tsang HWH, Corrigan PW. Self-stigma of people with schizophrenia as a predictor of their adherence to psychosocial treatment. Psychiatr Rehabil J. 2008; 32(2): 95104. doi: 10.2975/32.2.2008.95.104.

4. Rüsch N, Zlati A, Black G, Thornicroft G. Does the stigma of mental illness contribute to suicide? Br J Psychiatry. 2014; 205(4): 257-9. doi: 10.1192/bjp.bp.114.145755.

5. Ucok A. Why is the schizophrenic patient stigmatized? J Clin Psy. 2003; (Suppl. 1): 3-8.

6. Yuksel EG, Taskın EO. The attitudes and knowledge of the physicians and the medical school students towards mental disorders in Turkey. Anadolu Psikiyatri Derg. 2005; 6(2): 113-21.

7. Yildirim G, Ersan EE, Pinar SE, Kilic C. Assessment of health professionals' views nd beliefs about mental illnesses: A survey from Turkey. Int J Soc Sci. 2016; 5(5): 55-62.

8. Ross CA, Goldner EM. Stigma, negative attitudes and discrimination towards mental illness within the nursing profession: a review of the literature. J Psychiatr Ment Health Nurs. 2009; 16(6): 558-67. doi: 10.1111/j.1365-2850.2009.01399.x.

9. Gunay S, Bekitkol T, Ekitli GB, Yildirim S. Determination of the mental disorder beliefs of students in a Nursing du broja stigmatizirajućih reči koje koriste obe grupe, a najčešče korišćeni psihijatrijski dijagnostički izrazi sa svrhom stigmatizacije su poremećaji ličnosti. Broj stigmatizujućih reči koje koriste lekari veći je od medicinskih sestara $(\mathrm{p}=.000)$. Stručnjaci za mentalno zdravlje imaju pozitivnije stavove i na skali kratkoročnih i dugoročnih odnosa. Obe grupe pokazuju da je srednja ocena niža u dugoročnim nego u kratkoročnim odnosima.

Zaključak: Rad u oblasti mentalnog zdravlja ne dovodi do pozitivnih promena u smislu upotrebe jezika u svrhe stigmatizacije i smanjenja stigmatizijućih stavova u dugotrajnoj vezi sa pojedincima sa mentalnim bolestima. Preporučuje se povećanje svesti lekara o upotrebi stigmatizirajućeg jezika.

Ključne reči: Stigmatizacija, stavovi, lekar, medicinska sestra, mentalne bolesti, jezik.

Faculty. J Psychiatr Nurs 2016; 7(3): 129-34. doi: 10.5505/ phd.2016.43534

10. Knaak S, Mantler E, Szeto A. Mental illness-related stigma in healthcare Barriers to access and care and evidence-based solutions. Health Manage Forum. 2017; 30(2) 111-6. doi: 10.1177/0840470416679413.

11. Alpan A, Kocamanoglu E, Yuce F, Akcakmak G, Gunbal M, Asik E. et al. Students' attitudes against schizophrenia at Faculty of Health Sciences. Kirıkkale University Faculty of Medicine Journal. 2018; 20(1): 8-17. doi: 10.24938/ kutfd. 332740 .

12. Leucht S, Burkard T, Henderson J, Maj M, Sartorius N. Physical illness and schizophrenia: a review of the literature. Acta Psychiatr Scand. 2007; 116(5): 317-33. doi: 10.1111/j.1600-0447.2007.01095.x.

13. Laursen TM, Nordentoft M, Mortensen PB. Excess early mortality in schizophrenia. Annu Rev Clin Psychol 2014; 10: 425-48. doi: 10.1146/annurev-clinpsy-032813-153657.

14. Ucok A. Other people stigmatize...But, what about us? Attitudes of mental health professionals towards patients with schizophrenia. Arch Neuropsychiatr. 2007; 44(1): 108-16.

15. Bostanci N, Asti N. Nurses' attitudes toward persons with mental disorders. Dusunen Adam 2004; 17(2): 87-93.

16. Sercu C, Ayala RA, Bracke P. How does stigma influence mental health nursing identities? An ethnographic study of the meaning of stigma for nursing role identities in two Belgian Psychiatric Hospitals. Int J Nurs Stud. 2015; 52(1): 307-16. doi: 10.1016/j.ijnurstu.2014.07.017.

17. Bilge A, Cam O. The fight against stigma toward mental illness. TAF Prev Med Bull. 2010; 9(1): 71-8. 
18. Arı F, Oz F. Attitudes of doctors and nurses, working at primary health services, towards individuals with mental health problems. Journal of Hacettepe University School of Nursing. 2005; 12(1): 16-28.

19. Vistorte AOR, Ribeiro WS, Jaen D, Jorge MR, Evans-Lacko S, Mari JDJ. Stigmatizing attitudes of primary care professionals towards people with mental disorders: a systematic review. Int J Psychiatr Med. 2018; 53(4): 317-38. doi: 10.1177/0091217418778620.

20. Ozer U, Varlik C, Ceri V, Ince B, Delice MA. Change starts with us: stigmatizing attitudes toward mental illness and the use of stigmatizing language among mental health professionals. Dusunen Adam. 2017; 30(3): 224-32. doi: 10.5350/ DAJPN2017300306.

21. Szeto ACH, Luong D, Dobson KS. Does labeling matter? An examination of attitudes and perceptions of labels for mental disorders. Soc Psychiatry Psychiatr Epidemiol. 2013; 48(4): 659-71. doi: 10.1007/s00127-012-0532-7.

22. Lam DC, Poplavskaya EV, Salkovskis PM, Hogg LI, Panting H. An experimental investigation of the impact of personality disorder diagnosis on clinicians: can we see past the borderline? Behav Cogn Psychother. 2016; 44(3): 361-73. doi: $10.1017 / \mathrm{S} 1352465815000351$.

23. Taylor SM, Dear MJ. Scaling community attitudes toward the mentally ill. Schizophr Bull. 1981;7(2):225-40. doi: 10.1093/schbul/7.2.225.

24. Cohen JE. Statistical Power Analysis for the Behavioral Sciences. First ed., Hillsdale, NJ: Lawrence Erlbaum Associates Inc. 1988.

25. Özyiğit EŞ, Savaş HA, Ersoy MA, Yüce S, Tutkun H, Sertbaş G. Hemşirelerin ve hemşirelik öğrencilerinin şizofreniye ilişkin tutumları. New Symposium. 2004; 42(3): 105-12.

26. Kingdon D, Sharma T, Hart D. What attitudes do psychiatrists hold towards people with mental illness. B J Psych Bulletin. 2004; 28(11): 401-6.

27. Lauber C, Anthony M, Ajdacic-Gross V, Rossler W. What about psychiatrists' attitude to mentally ill people? Eur Psychiatry. 2004; 19(7): 423-7. doi: 10.1016/j.eurpsy.2004.06.019

28. Alexander L, Link B. The impact of contact on stigmatizing attitudes toward people with mental illness. J Ment Health. 2003; 12(3): 271-89. doi: 10.1080/0963823031000118267.

29. Granados-Gamez G, Lopez Rodríguez MD, Corral Granados A, Marquez-Hernandez VV. Attitudes and beliefs of nursing students toward mental disorder: the significance of di- rect experience with patients. Perspect Psychiatr Care. 2017; 53(2): 135-43. doi: 10.1111/ppc.12147.

30. Crips AH, Gelder MG, Rix S, Meltzer HI, Rowlands OJ. Stigmatization of people with mental illness. Br J Psychiatry. 2000; 177(1): 4-7. doi: 10.1192/bjp.177.1.4.

31. Ozden A, Essizoglu A. Attitudes of turkish nurses towards schizophrenic patients. Dusunen Adam. 2004; 17(3): 146-53.

32. Werner S. Public stigma in intellectual disability: do direct versus indirect questions make a difference? J Intellect Disabil Res. 2015; 59(10): 958-69. doi: 10.1111/jir.12207.

33. Arabaci LB, Cam MO. The attitudes nurses working at psychiatric hospitals in Turkey have towards forensic psychiatric patients and the associated factors. [Article in Turkish]. Turk Psikiyatri Derg. 2013; 24(4): 253-9.

34. Loch AA, Guarniero FB, Lawson FL, Hengartner MP, Rössler W, Gattaz WF et al. Stigma toward schizophrenia: do all psychiatrists behave the same? Latent profile analysis of a national sample of psychiatrists in Brazil. BMC Psychiatry. 2013; 13(1): 92-102. doi: 10.1186/1471-244X-13-92.

35. Chen MD, Chang YC. Personnel attitudes toward people with mental illness at a psychiatric hospital in Taiwan. Int J Soc Psychiatry. 2016; 62(4): 361-8. doi: 10.1177/0020764016634385.

36. Jensen ME, Pease EA, Lambert K, Hickman DR, Robinson $\mathrm{O}$, McCoy $\mathrm{KT}$ et al. Championing person-first language: a call to psychiatric mental health nurses. J Am Psychiatr Nurses Assoc. 2013; 19(3): 146-51. doi: 10.1177/1078390313489729.

37. Cuttler C, Ryckman M. Don't call me delusional: Stigmatizing effects of noun labels on people with mental disorders. Stigma and Health. 2019; 4(2): 118-25. doi: 10.1037/ sah0000132.

38. Sheehan L, Nieweglowski K, Corrigan P. The stigma of personality disorders. Curr Psychiatry Rep. 2016; 18(11): 1-7. doi: 10.1007/s11920-015-0654-1.

39. Rusch N, Schiel S, Corrigan PW, Leihener F, Jacob GA, Olschewski M et al. Predictors of dropout from inpatient dialectical behavior therapy among women with borderline personality disorder. J Behav Ther Exp Psychiatry. 2008; 39(4): 497-503. doi: 10.1016/j.jbtep.2007.11.006.

40. Demiroren M, Senol Y, Kosan AMA, Saka MC. Educational needs assessment of stigmatization towards mental illness in medical education: qualitative and quantitative approach. Anadolu Psikiyatri Derg. 2015; 16(1): 22-9. doi: 10.5455/apd.45731

\section{Correspondence to/Autor za korespondenciju}

Seda Kirc1 Ercan (ORCID: 0000-0002-1363-0349)

University of Health Sciences, Konya Training and Research Hospital, Psychiatry Clinic, Konya, Turkey e-mail: drsedakirci@yahoo.com 